\title{
PERAN TIPE GAMBAR, TAGAR, JUMLAH LIKES DAN INFORMASI HARGA PADA INSTAGRAM TERHADAP INTENSI MEMBELI
}

\author{
Hasrini Sari"), Lidia Anggraeni \\ Program Studi Teknik Industri, Institut Teknologi Bandung
}

(Received: October 22, 2018/ Accepted: July 24, 2019)

\begin{abstract}
Abstrak
Penelitian ini bertujuan untuk mengetahui pengaruh desain visual post Instagram dalam hal tipe gambar, tagar, jumlah likes, dan caption berupa informasi harga, terhadap tingkat atensi visual pemirsa, dan intensi pembelian. Keempat elemen tersebut dihipotesiskan akan mempengaruhi atensi visual pemirsa, dan pada akhirnya mempengaruhi intensi membeli. Metode desain eksperimen digunakan untuk menguji hipotesis dengan alat bantu eye tracker untuk mengukur atensi visual. Instagram dari sebuah perusahaan UKM yang menjual tas tangan (pouch) digunakan sebagai objek penelitian. Delapan stimulus berpasangan (gambar produk dan konsumen) yang merupakan dummy post Instagram dirancang berdasarkan hipotesis penelitian, dan satu pasang stimulus post Instagram yang ada saat ini digunakan sebagai kontrol. Empat puluh partisipan dipaparkan kesembilan stimulus menggunakan pendekatan within subject design. Dari hasil statistik deskriptif, ditemukan bahwa partisipan lebih menyukai tipe gambar produk, dan stimulus yang paling disukai yang menampilkan caption keterangan harga, hashtag serta jumlah likes yang banyak. Uji statistik inferensial menunjukkan adanya perbedaan tipe gambar (gambar produk dan gambar konsumen) dan jumlah likes mempengaruhi tingkat atensi visual pemirsa, serta tidak ada hubungan antara tingkat atensi terhadap tampilan Instagram dengan intensi membeli.
\end{abstract}

Kata kunci: Intensi membeli; atensi visual; statistik inferensia; desain eksperimen

\begin{abstract}
[Role Of Image Type, Hashtag, Number Of Likes And Pricing Information On Instagram Against Intensi Buying/ This research is intended to investigate the influence of visual design of Instagram concerning picture type, hashtag, number of likes, and price information, on intention to buy. These elements are suggested to influence visual attention of the audience, and ultimately influence the intention to buy. Experiment design method is implemented to test the hypotheses using an eye tracker device to measure visual attention. An Instagram post from an SME offering pouch is used as a research object. Eight paired of dummy Instagram posts (the product picture and the consumer picture) are designed to test the research hypotheses, and a pair of existing Instagram post acts as a control stimulus. Forty participants are exposed to all of the stimuli using a within-subject design approach. Descriptive statistic analysis shows that participants like product picture more than consumer, and stimulus containing price information, hashtag, and many likes. Inferential statistic analysis shows that picture type and likes all influence visual attention and no significant relationship between visual attention and intention to buy.
\end{abstract}

Keywords: Intention to buy; visual attention; statistic inferensia; desain eksperimen

*)Penulis Korespondensi.

E-mail: hasrinis@gmail.com 


\section{Pendahuluan}

E-commerce atau perdagangan elektronik merupakan transaksi bisnis yang terjadi dalam jaringan elektronik, seperti internet (Pearson, 2008). Indonesia merupakan negara dengan pertumbuhan e-commerce tertinggi di dunia (Abdurrahman, 2017). Beberapa tahun terakhir, menurut data sensus ekonomi 2016 dari Badan Pusat Statistik (BPS) menyebutkan bahwa semakin banyak pelaku usaha yang mengembangkan usaha ke arah digital. Industri e-commerce Indonesia tumbuh sekitar tujuh belas persen dalam sepuluh tahun terakhir (Abdurrahman, 2017). Salah satu media yang makin banyak digunakan adalah penjualan melalui media sosial. Media sosial Instagram merupakan platform daring baru yang menonjolkan aspek visual. Indonesia merupakan negara dengan pengguna aktif di Instagram terbanyak ketiga di dunia dengan jumlah pengguna aktif sebanyak 53 juta pengguna (Hootsuite, 2018). Oleh karena itu, makin banyak pelaku bisnis yang memanfaatkan media sosial Instagram sebagai media promosinya.

Namun demikian, seiring dengan semakin banyaknya pihak yang menggunakan Instagram sebagai media promosi, para penggunanya mengalami keberlimpahan informasi. Hal ini menyebabkan para pengguna akan melakukan proses seleksi terhadap paparan yang diterimanya. Oleh karena itu, para pemilik usaha perlu mengetahui faktor-faktor yang mempengaruhi intensi pembelian dari calon konsumennya. Terlebih lagi pada pemasaran digital hal yang perlu diperhatikan bukan hanya mengenai seberapa banyak penjualan produk tetapi juga interaksi dengan pengikutnya (Khan, 2012).

\section{Perumusan Hipotesis}

Pada dasarnya, promosi pada Instagram untuk dapat meningkatkan intensi pembelian ditentukan oleh beberapa faktor. Menurut penelitian Shojaee \& Azman (2013), untuk melakukan strategi promosi dalam Instagram terdapat 3 faktor yang harus diperhatikan yakni:

\section{Brand Exposure (Paparan Merek)}

Dalam strategi promosi untuk membangun sebuah citra produk, setelah menemukan target pelanggan dari produk, sebuah produk harus mulai membuka dirinya dengan strategi yang dinamakan dengan brand exposure. Merek sendiri berperan menjadi pembeda antar produk/layanan yang tersedia di pasar, serta memberikan kesan tertentu di mata para pelanggannya (Bakhtiar dan Jayanto, 2015). Paparan merek membantu pelanggan dalam menentukan fokusnya terhadap beberapa merek produk atau jasa yang sedang diminati. Paparan merek dapat membentuk tingkah laku orang yang bukan pelanggan melalui mekanisme kognitif melalui pembentukan tingkah laku di bawah alam sadar seseorang. Berdasarkan teori ini, partisipasi yang tidak disengaja dapat terjadi dalam hampir semua alat komunikasi pemasaran. Paparan merek akan meningkatkan level dari brand awareness (kesadaran merek), keinginan konsumen untuk membeli dan brand attitude (sikap terhadap merek) (Laroche dkk, 1996). Dalam Instagram, salah satu elemen yang dapat membantu meningkatkan tingkat paparan merek adalah penggunaan hashtag (tanda pagar/ tagar) dalam posting Instagram.

Tagar (hashtag) seringkali digunakan untuk memudahkan calon pelanggan dalam menemukan produk ataupun merek produk di Instagram. Penggunaan tagar mempermudah suatu merek produk untuk meningkatkan paparan merek kepada suatu grup pelanggan. Walaupun penggunaannya tidak dapat meningkatkan tingkat interaksi dengan pelanggan secara eksponensial, tagar membuat calon pelanggan dapat menemukan suatu merek produk. Untuk meningkatkan kesadaran merek, sebaiknya suatu merek produk menggunakan tagar yang memudahkan untuk ditemukan oleh calon pelanggannya (Sjoberg, 2017). Menurut studi yang telah dilakukan sebelumnya (Measured, 2014), sebuah post Instagram yang menggunakan minimal 1 tagar akan mendapatkan rata-rata 12,6\% lebih banyak tingkat interaksi (engagement rate).

2. Customer Engagement (interaksi dengan pelanggan)

Dalam saluran pemasaran daring, pemirsa (viewer) dapat menciptakan suatu promosi bagi suatu merek. Sebagai contoh, terdapat seorang permirsa yang jarang membeli produk dari suatu perusahaan, tetapi pemirsa tersebut selalu memberikan ulasan mengenai produk tersebut. Ulasan ini dapat memberikan pengaruh pada calon pelanggan. Jadi, perusahaan perlu menambahkan perspektif baru dalam memandang brand awareness melalui media sosial, yakni menjalin engagement atau interaksi dengan pemirsanya (Shojaee \& Azman, 2013)

Tingkat interaksi di Instagram dapat diukur melalui banyaknya mention, jumlah likes, tanggapan, dan lain sebagainya. Penelitian ini hanya memperhatikan satu aspek yaitu jumlah likes dari sebuah post Instagram. Pada dasarnya, likes menunjukkan reaksi positif terhadap suatu post di Instagram. Sebuah konten yang menerima reaksi positif dan tidak berbayar dari pengikutnya adalah salah satu alat pemasaran yang sangat penting bagi suatu merek. Hal ini dikarenakan target pelanggan lebih memilih untuk percaya kepada rekomendasi dari orang-orang atau temannya dibandingkan dengan iklan berbayar (Zhou, 2017).

3. Electronic Word of Mouth (e-WOM)

Electronic-WOM merupakan perluasan dari word of mouth. E-WOM adalah komunikasi dengan 
tipe banyak-ke-banyak dan antara pengirim ataupun penerima yang tidak kenal satu sama lainnya (Shojaee \& Azman, 2013). Akan tetapi, efek dari eWOM ini cukup tinggi karena banyaknya orang yang terlibat dalam sebuah diskusi mengenai produk/layanan tertentu. E-WOM membantu perusahaan untuk mengurangi biaya iklan. Hal ini disebabkan oleh cerita pengalaman yang positif dari pelanggan dianggap lebih efektif dibandingkan dengan iklan dari produk itu sendiri (Ohman, 2017). Konsumen lebih percaya akan pesan dan pengalaman dari para pelanggan lainnya dibandingkan pesan dari perusahaan penyedia produk/ layanan itu sendiri (Shojaee \& Azman, 2013).

Di samping itu, untuk membangkitkan persepsi yang positif di mata pemirsa Instagram, penggunaan kata-kata yang tepat dan foto yang baik menjadi faktor penting yang perlu dipehatikan. Instagram merupakan media sosial yang menekankan penggunaan dari konten secara visual (Moreau, 2016) dan merupakan media yang tepat untuk membangun merek produk karena posting gambar lebih disukai dibandingkan dengan tulisan di media sosial (Ohman, 2017). Menurut penelitian Miles (2015), pengguna lebih senang untuk melihat foto yang bisa terhubung dengan mereka secara emosional dibandingkan dengan teknik foto yang bagus. Contoh dari foto tersebut adalah tujuan liburan, pantai, tempat yang indah, wajah orang yang cantik, sepatu, gaun, dan matahari terbenam. Sementara Zhou (2017) menemukan bahwa tipe gambar, penggunaan tagar, keterangan gambar, warna, sudut pandang gambar, dan bentuk gambar merupakan beberapa faktor yang memengaruhi tingkat atensi individu, sikap terhadap merek, dan rekognisi merek pada Instagram.

Perbedaan tipe gambar juga dapat menimbulkan perbedaan tingkat atensi dan tingkat interaksi (engagement) dari pengguna. Gambar dengan wajah seseorang akan menerima jumlah likes 38\% lebih banyak. Sedangkan, menurut King (2015), gambar di Instagram dengan latar belakang lebih terang akan mendapatkan tingkat interaksi yang lebih tinggi dibandingkan dengan gambar dengan latar belakang gelap. Penelitian tersebut juga mengungkapkan bahwa gambar yang mempunyai satu warna dominan akan mendapatkan tingkat interaksi yang lebih tinggi.

Bakhshi dan Gilbert (2015) meneliti mengenai gambar apa yang memperoleh tingkat interaksi paling tinggi di Instagram. Hasil penelitian tersebut menunjukkan bahwa gambar berwarna lebih sering dishare dan memperoleh jumlah likes yang lebih banyak dibandingkan gambar yang hitam putih.

Gambar orang seringkali digunakan oleh perusahaan untuk meningkatkan tingkat loyalitas dan tingkat atensi pelanggan. Gambar dengan wajah yang "ramah" akan meningkatkan tingkat kepercayaan dan atensi pengguna. Selain itu, Ohman (2017) melakukan penelitian terhadap hubungan antara konten visual dalam Instagram dengan atensi pemirsa. Hasil dari penelitian ini menunjukkan beberapa tipe post dalam Instagram yang akan meningkatkan tingkat interaksi dengan permirsanya yakni post Instagram yang memperlihatkan gambar orang atau binatang di dalamnya.

Penelitian Small \& Verrochi (2009) menunjukkan bahwa ketika orang melihat wajah seseorang yang sedih, konsumen juga akan merasa sedih. Gambar dengan ekspresi wajah akan menarik perhatian pengguna.

Selain tipe gambar dan konten gambar, tingkat atensi pengguna Instagram juga dipengaruhi oleh informasi yang dicantumkan pada keterangan gambar (caption). Pengguna cenderung memperhatikan informasi yang dianggap penting dan relevan bagi pemilihan keputusan pembelian (Menon, 2016). Penelitian Menon (2016) juga menunjukkan bahwa atribut informasi dengan tingkat kepentingan yang tinggi menerima jumlah atensi yang lebih besar. Wagner (2007) mengatakan bahwa pengguna cenderung melihat ke arah informasi harga dan cenderung mencari produk dengan harga yang murah. Penelitian lain yang dilakukan oleh Zhou (2017) terhadap pengaruh dari desain visual posting Instagram terhadap tingkat atensi visual, brand recognition, dan brand attitude menemukan bahwa terdapat hubungan antara di antara variabel-variabel tersebut.

Berdasarkan uraian di atas, penelitian ini akan mempertimbangkan pengaruh dari empat elemen informasi yang ditampilkan pada Instagram, yaitu tanda pagar/ tagar (hashtag), jumlah likes, tipe gambar dan informasi harga yang ditampilkan pada keterangan gambar. Perbedaan pada keempat elemen tersebut akan menyebabkan perbedaan atensi visual dari pemirsa Instagram. Hipotesis penelitian adalah sebagai berikut:

H1: Perbedaan tipe gambar mempengaruhi atensi visual pemirsa Instagram

H2: Informasi harga pada keterangan gambar mempengaruhi atensi visual pemirsa Instagram

H3: Jumlah likes mempengaruhi atensi visual pemirsa Instagram

H4: Tagar mempengaruhi atensi visual pemirsa Instagram

Intensi pembelian atau purchase intention adalah kecenderungan pelanggan untuk membeli sebuah merek secara umum berdasarkan pertimbangan kesesuaian antara motif pembelian dengan atribut atau karakteristik dari merek (Belch, 2004). Penelitian terdahulu menunjukkan terdapat faktor-faktor yang menyebabkan pelanggan mau melakukan pembelian. Pada penelitian 
sebelumnya yang dilakukan oleh Pechmann dan Stewart (1990), ditemukan hubungan positif antara atensi terhadap iklan komparatif dengan intensi membeli untuk produk-produk dengan pangsa pasar relatif rendah. Peneliti lainnya, yaitu Huddleston dkk (2015) dalam studinya menemukan hubungan positif antara atensi visual terhadap penanda yang berisi informasi produk atau harga, dengan kemungkinan untuk membeli. Pada penelitian ini, diduga bahwa semakin besar atensi pemirsa secara visual terhadap tampilan di Instagram, maka kecenderungan untuk membeli produk/ layanan ditawarkan pada Instagram tersebut akan semakin besar.

H5: Atensi visual pemirsa Instagram berpengaruh positif terhadap intensi pembelian

\section{Metode Penelitian}

Metode yang digunakan pada penelitian ini terutama merujuk pada tiga penelitian sebelumnya yang menggunakan alat bantu eye tracker dalam pengumpulan data, yaitu penelitian yang dilakukan oleh Pretorius dan Calitz (2011), Zhou (2017), dan Ohman (2017). Contoh proses pada saat pengambilan data dapat dilihat pada Gambar 1 berikut.

Penelitian ini sendiri bertujuan untuk meneliti pengaruh desain visual post Instagram dalam hal tipe gambar, jumlah likes, tagar dan caption berupa informasi harga, terhadap tingkat atensi visual pemirsa, dan intensi pembelian. Selain hubungan langsung, penelitian ini juga ingin melihat lebih jauh pengaruh interaksi di antara komponen visual pada post Instagram. Hipotesis penelitian selengkapnya dapat dilihat pada Gambar 1. Model penelitian dapat dilihat pada Gambar 2.

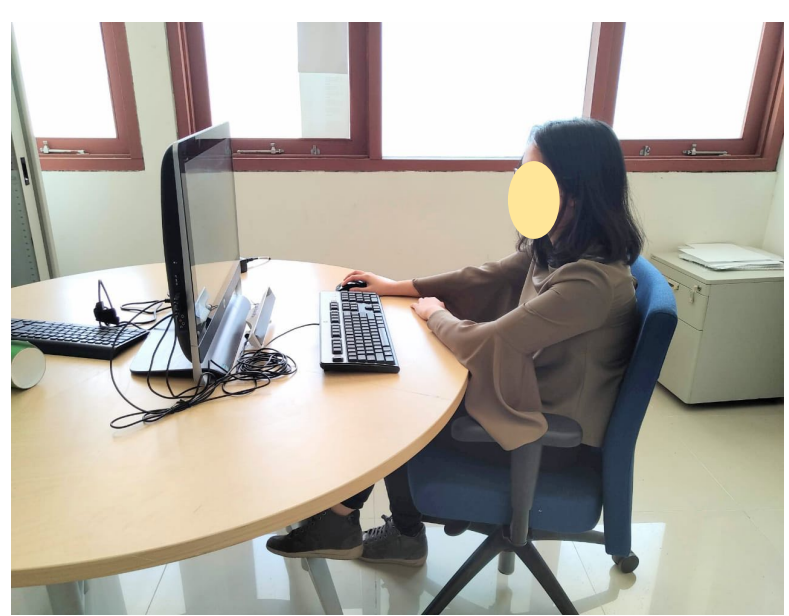

Gambar 1. Contoh Proses Pengambilan Data

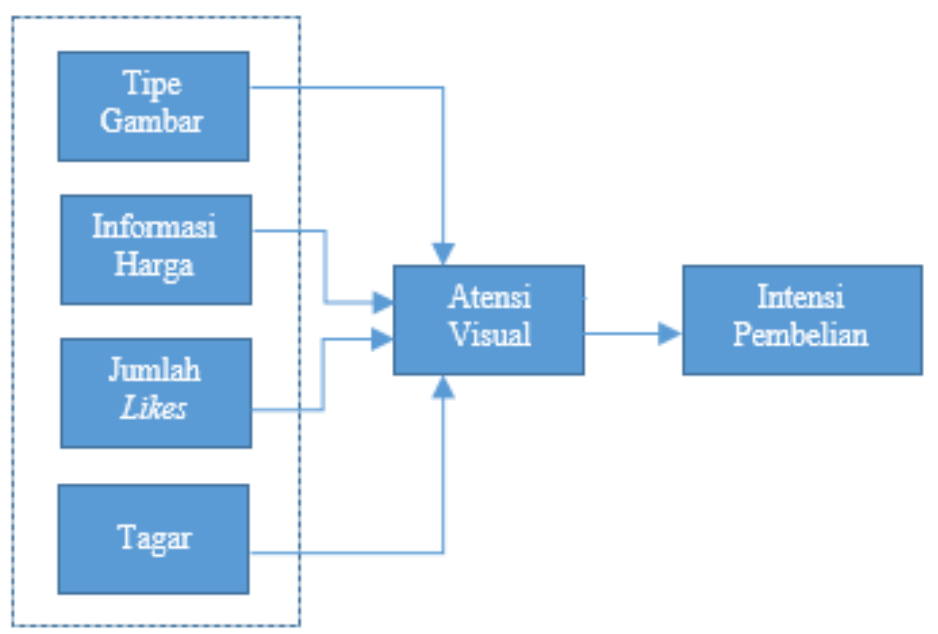

Gambar 2. Model Penelitian 
Tabel 1. Daftar Stimulus untuk Masing-Masing Tipe Gambar (Produk dan Konsumen)

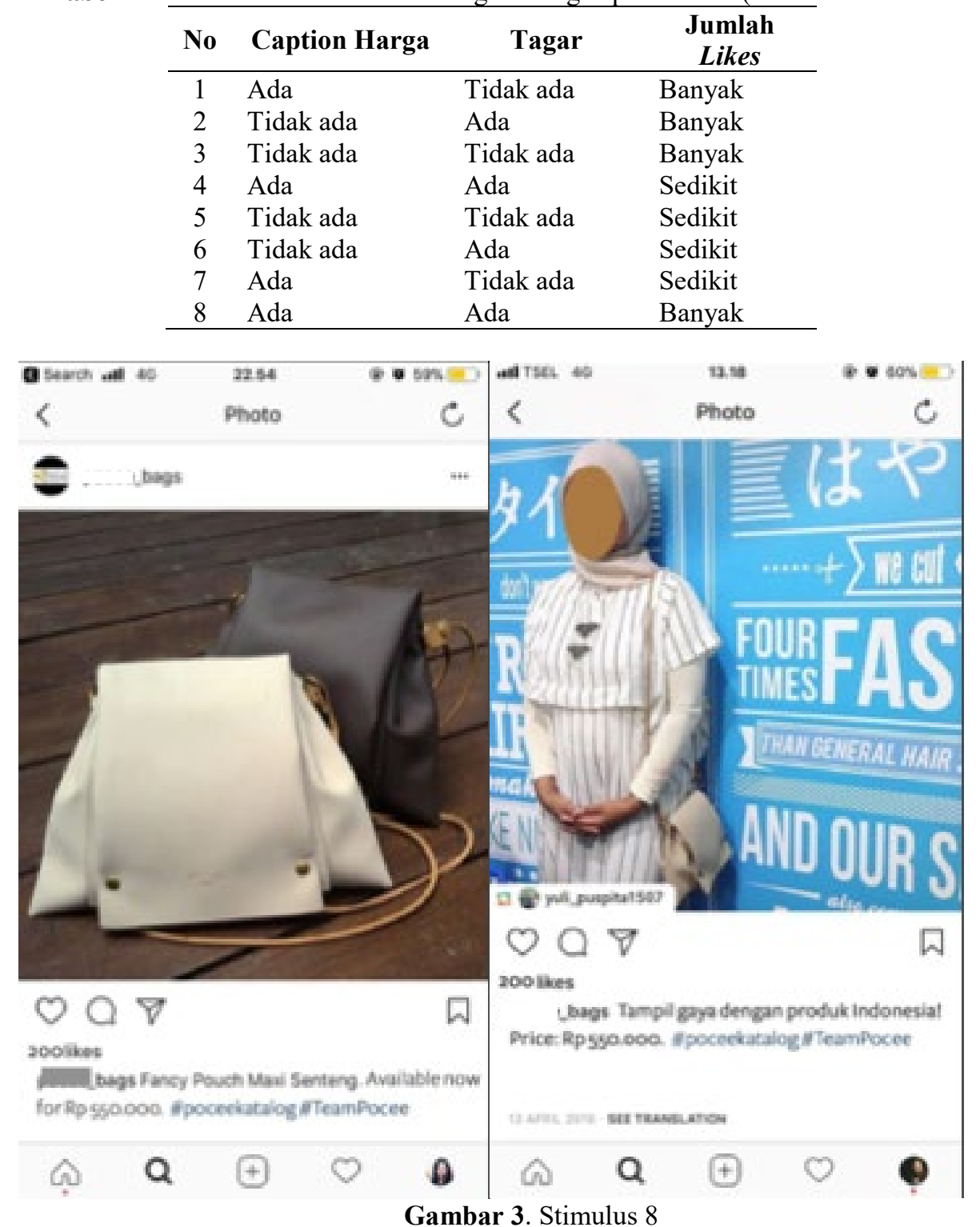

Metode penelitian yang dipilih adalah desain eksperimen. Instagram dari sebuah perusahaan UKM yang menjual tas tangan (pouch) digunakan sebagai kasus dalam penelitian ini. Perusahaan tersebut saat ini sedang mengalami masalah penurunan penjualan melalui saluran daring termasuk salah satunya Instagram.

Berdasarkan hipotesis penelitian, terdapat 4 faktor dengan 2 level yakni faktor tipe gambar (gambar produk dan konsumen), caption informasi harga (ada dan tidak ada keterangan harga), tagar (ada dan tidak ada tagar), dan jumlah likes ( $15 \%$ dan $75 \%$ dari jumlah followers). Keempat faktor dan 2 level ini kemudian diterjemahkan ke dalam bentuk delapan stimulus berpasangan (gambar produk dan konsumen) yang merupakan dummy post Instagram. Sementara satu pasang stimulus digunakan sebagai kontrol, yaitu post Instagram yang ada saat ini. Contoh stimulus 8 dapat dilihat pada Gambar 3.

Eksperimen pendahuluan dilakukan untuk mendapatkan protokol eksperimen yang sesuai dengan tujuan penelitian, serta untuk memastikan bahwa skenario penelitian, instruksi penelitian, dan prosedur penelitian sudah baik. Tujuan lainnya adalah untuk memastikan tidak adanya kesalahan teknis yang terjadi terhadap perangkat keras ataupun perangkat lunak yang akan dipakai saat penelitian utama berlangsung.

Pengumpulan data dilakukan dengan menggunakan within subject design terhadap 40 partisipan yang dipaparkan kesembilan pasang stimulus tersebut. Untuk menghilangkan pengaruh urutan pemaparan, maka metode counter balancing digunakan 
untuk mengacak urut-urutan paparan stimulus kepada setiap partisipan.

Berikut ini merupakan kriteria dari partisipan untuk penelitian ini:

1. Berusia antara 18-24 tahun.

2. Partisipan tidak buta warna.

3. Partisipan berjenis kelamin wanita.

4. Partisipan sering menggunakan aplikasi media sosial Instagram.

5. Partisipan pernah menggunakan Instagram untuk berbelanja daring dan mem-follow toko daring di Instagram.

6. Partisipan tergolong ke dalam menengah ke atas dalam status sosial.

7. Partisipan belum mengetahui mengenai merek yang menjadi kasus pada penelitian ini

Tingkat atensi visual diukur melalui frekuensi fiksasi dan durasi fiksasi. Kedua data ini diperoleh dari eye tracker. Fiksasi adalah pergerakan mata saat mata fokus pada sebuah objek dalam waktu antara 50 hingga $500 \mathrm{~ms}$ (Bojko, 2006). Fiksasi dapat menunjukkan proses saat pengguna mengambil informasi dan menunjukkan banyaknya data yang diolah dalam sebuah titik. Penggunaan fiksasi untuk mengukur atensi sudah pula dilakukan oleh penelitian terdahulu. Pretorius dan Calitz (2011) melakukan penelitian terhadap hubungan antara tingkat atensi dengan sikap terhadap post Instagram. Hasil dari penelitian menunjukkan bahwa jumlah fiksasi atau tingkat atensi partisipan berbanding lurus dengan tingkat preferensi konsumen terhadap post Instagram tersebut.

Intensi pembelian diukur dengan pertanyaan apakah partisipan memiliki niat untuk membeli produk pouch yang ditampilkan pada stimulus dengan skala Likert. Pertanyaan-pertanyaan ini diajukan pada partisipan setelah semua stimulus dipaparkan. Di samping itu, ada pula beberapa pertanyaan tambahan mengenai stimulus yang paling disukai dan tidak disukai di antara kesembilan pasang stimulus, serta beberapa pertanyaan lainnya yaitu partisipan diminta untuk menyebutkan hal-hal yang mereka ingat mengenai stimulus yang telah dilihatnya. Kemudian, pertanyaan mengenai sikap terhadap produk juga ditanyakan untuk mengetahui kecenderungan penilaian partisipan terhadap produk, apakah positif atau negatif.

Pengolahan data yang diperoleh dilakukan dengan menggunakan tiga metode pengolahan data yakni statistika deskriptif, heat map, dan uji statistika inferensial ANOVA dan regresi. Heat map untuk setiap stimulus dihasilkan dari Gazepoint Analysis alat eye tracker. Heat map yang ditampilkan berisi durasi yang sudah diatur nilai minimum dan maksimumnya sehingga dapat dibandingkan satu sama lain. Warna pada heat map menunjukkan durasi (dalam satuan detik) dari fiksasi mata. Urut-urutan durasi fiksasi dari paling rendah ke paling tinggi adalah warna biru, hijau, kuning dan merah. Jadi, warna merah menunjukkan durasi fiksasi mata yang paling lama (Bojko, 2006).

\section{Hasil dan Pembahasan}

Jika ditinjau dari elemen dari post Instagram yang menjadi fokus partisipan pertama kali, maka ditemukan bahwa partisipan lebih fokus pada gambar yang ada di Instagram dibandingkan melihat caption dari gambar tersebut. Hal ini menunjukkan bahwa konsumen lebih tertarik untuk melihat kepada tampilan produk dahulu kemudian baru melihat kepada caption yang berisikan keterangan lebih lanjut dari produk yang ditawarkan di Instagram tersebut.

Analisis lebih jauh terhadap nilai modus dan ratarata untuk data sikap terhadap stimulus dari masingmasing partisipan, ditemukan bahwa partisipan lebih menyukai tipe gambar produk. Hasil penelitian ini tidak sejalan dengan hasil penelitian yang dilakukan oleh Ohman (2017) yang menemukan bahwa post Instagram dengan gambar orang atau binatang lebih menarik perhatian pemirsa. Namun demikian, total durasi fiksasi partisipan terhadap stimulus dengan tipe gambar konsumen (rata-rata $=33,96$ detik, $\mathrm{SD}=12,91$ ) relatif lebih lama dibandingkan dengan gambar produk (Ratarata=31,95 detik, $\mathrm{SD}=13,24)$. Jadi partisipan melihat post Instagram dengan gambar konsumen relatif lebih lama namun kurang membangkitkan sikap positif. Penelitian lebih lanjut yang lebih berfokus pada tipe-tipe gambar perlu dilakukan untuk mengkonfirmasi hasil penelitian ini.

Di samping itu, stimulus yang paling disukai oleh partisipan adalah stimulus 8 sementara yang paling tidak disukai adalah stimulus 9. Ini berarti pemirsa paling menyukai post Instagram yang menampilkan caption keterangan harga, tagar serta jumlah likes yang banyak.

Data mengenai kemampuan partisipan untuk mengingat kembali pada stimulus yang sudah ditampilkan, untuk jumlah likes diukur dengan 4 skala yakni dari 0 jika sama sekali tidak ingat jumlah likes hingga 3 jika ingat semua jumlah likes yang ada dalam penelitian. Data mengenai ingatan tentang harga dibagi menjadi 0 dan 1 , yaitu 0 jika partisipan tidak ingat sama sekali dan 1 jika partisipan ingat harga dari produk. Data mengenai ingatan tentang tagar diukur dengan 3 skala yakni 0 jika partisipan tidak ingat sama sekali tagar yang digunakan hingga 2 jika partisipan ingat semua tagar yang digunakan.

Hasil analisis statistik deskriptif menunjukkan bahwa 53\% ingat atau ingat sebagian jumlah likes pada stimulus; semua partisipan (100\%) ingat dengan harga yang tercantum pada caption; dan $96 \%$ ingat atau ingat sebagian tagar yang tercantum pada stimulus. Hal ini menunjukkan bahwa harga merupakan faktor penting sehingga informasi tersebut langsung tersimpan dalam ingatan semua partisipan. 
Intensi pembelian diukur dengan menggunakan skala Likert dari 1 yakni "Sangat Tidak Setuju" hingga 5 "Sangat Setuju". Hasil pengolahan statistik deskriptif menunjukkan bahwa prosentase partisipan yang tidak ingin membeli dan yang ingin membeli produk yang ditawarkan hampir berimbang, yaitu 37,5\% dan 32,5\%. Jumlah ini hampir sebanding dengan jumlah partisipan yang menyatakan ragu-ragu untuk membeli, yaitu sebesar $30 \%$. Analisis lebih lanjut terhadap pengolahan data deskriptif untuk sikap terhadap produk menunjukkan bahwa 50\% partisipan setuju bahwa produk yang ditampilkan merupakan produk yang baik, namun $62,5 \%$ berpendapat bahwa produk tersebut kurang memikat. Dari hasil ini, dapat disimpulkan bahwa promosi produk yang dilakukan melalui Instagram belum mampu mendorong partisipan untuk membeli produk tersebut meskipun produk dinilai baik.

Hasil heat map menunjukkan area yang menjadi perhatian partisipan, ditandai dengan waktu melihat yang lebih lama. Heat map merupakan cara yang mudah dan praktis untuk melihat hasil penelitian eye-tracking namun hasilnya tidak dapat memberikan informasi lebih jauh mengenai signifikansi antar faktor (Bojko, 2013). Informasi signifikansi antar faktor dapat diketahui dengan menggunakan uji statistik inferensial.

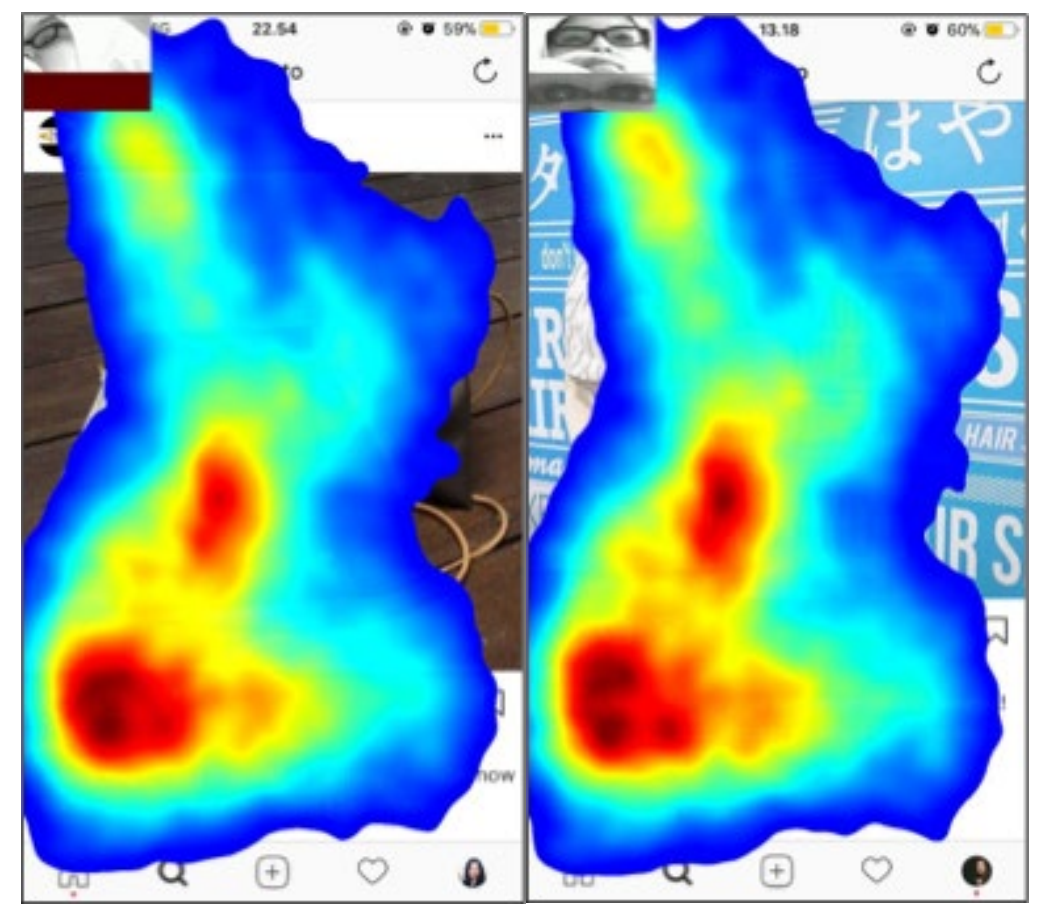

Gambar 4. Heat map Stimulus 8

Tabel 2. Hasil Pengolahan Uji t Berpasangan ( $\mathrm{df}=39 ; \alpha=0,1)$

\begin{tabular}{cccccc}
\hline Hubungan & Indikator & $\boldsymbol{t}$ & $\boldsymbol{p}$ & Ket. & Hipotesis \\
\hline Tipe gambar & Durasi & 1,70 & 0,09 & Sig & H1 diterima \\
$\rightarrow$ Atensi visual & Frekuensi & 1,75 & 0,09 & Sig & \\
Info harga & Durasi & $-1,06$ & 0,29 & Tak sig. & H2 ditolak \\
$\rightarrow$ Atensi visual & Frekuensi & $-1,29$ & 0,21 & & \\
Jumlah likes & Durasi & $-2,47$ & 0,02 & Sig & H3 diterima \\
$\rightarrow$ Atensi visual & Frekuensi & $-3,05$ & 0,00 & Sig & \\
Tagar $\rightarrow$ Atensi & Durasi & $-0,87$ & 0,39 & Tak sig. & H4 ditolak \\
visual & Frekuensi & $-1,60$ & 0,12 & & \\
\hline
\end{tabular}

Tabel 3. Hasil Pengolahan Uji Anova

\begin{tabular}{ccccc}
\hline Hubungan & $\boldsymbol{F}$ & $\boldsymbol{p}$ & Ket. & Kesimpulan \\
\hline Jumlah likes x Gambar & 0,02 & 0,89 & Tak sig. & Tidak ada interaksi \\
Tipe Gambar x Info Harga & 0,71 & 0,41 & Tak sig. & Tidak ada interaksi \\
Jumlah likes x Info Harga & 0,19 & 0,05 & Sig. & Ada interaksi \\
\hline
\end{tabular}


Tabel 4. Hasil Pengolahan Regresi Ordinal

\begin{tabular}{cccccl}
\hline Hubungan & Indikator & $\boldsymbol{\beta}$ & $\boldsymbol{p}$ & Ket. & Hipotesis \\
\hline Atensi visual & Durasi & $-0,00$ & 0,96 & Tak sig. & \multirow{2}{*}{ H8 ditolak } \\
$\rightarrow$ Intensi Pembelian & Fiksasi & & & & \\
\hline
\end{tabular}

Pada Gambar 4 untuk post gambar produk, terlihat bahwa perhatian partisipan terfokus pada gambar di mana tercantum merek produk, serta informasi yang tercantum di bawah gambar tersebut. Sementara untuk post gambar konsumen, perhatian utama partisipan terarah pada produk yang dikenakan konsumen serta informasi di bawah gambar.

Untuk analisis statistik inferensial, terlebih dulu semua data diuji asumsi normalitas. Hasilnya menunjukkan bahwa data berdistribusi normal. Kemudian, dilakukan pengujian terhadap hipotesis penelitian menggunakan uji $t$ berpasangan untuk menguji hipotesis penelitian 1 hingga hipotesis 4 dengan bantuan SPSS. Hasil pengolahan data dapat dilihat pada Tabel 2.

Analisis menggunakan $\mathrm{Uji} t$ berpasangan bertujuan untuk menguji hipotesis penelitian mengenai pengaruh dari tipe gambar, informasi harga, jumlah likes dan tagar. Jadi, dapat disimpulkan bahwa perbedaan tipe gambar (gambar produk dan gambar konsumen) dan jumlah likes mempengaruhi tingkat atensi visual partisipan, sementara informasi harga dan tagar tidak mempengaruhi tingkat atensi visual partisipan. Pengaruh informasi harga yang tidak signikan terhadap atensi berbeda dengan hasil penelitian Huddleston dkk (2015).

Oleh karena itu, dilakukan pengujian dengan analisis statistik lebih lanjut untuk mengkaji keberadaan dari pengaruh interaksi antara variabel jumlah likes, informasi harga, dan tipe gambar, terhadap atensi visual dengan menggunakan uji ANOVA. Hasil pengujian dapat dilihat pada Tabel 3 .

Dari Tabel 3, terlihat bahwa interaksi antara jumlah likes dan harga mempengaruhi atensi visual partisipan Instagram. Jadi, informasi harga jika berdiri sendiri tidak mempengaruhi atensi partisipan, namun informasi harga yang disertai dengan informasi jumlah likes akan mampu menarik atensi visual pemirsa Instagram.

Di sisi lain, jika ditinjau lebih jauh lagi dengan melihat urutan faktor yang menarik atensi partisipan pertama kali antara harga dengan likes, ditemukan bahwa harga dari suatu produk di Instagram merupakan hal yang pertama kali menarik perhatian dari calon konsumen dibandingkan jumlah likes. Hal ini diduga karena konsumen cenderung untuk pertama kali memperhatikan informasi yang mempunyai efek lebih tinggi dalam keputusan pembelian (Menon, 2016). Jadi, harga diduga mempunyai efek yang lebih tinggi terhadap keputusan pembelian konsumen dibandingkan jumlah likes di Instagram.
Namun demikian, informasi harga tidak berpengaruh langsung pada atensi visual, diduga karena harga produk dipersepsikan relatif mahal berdasarkan komentar dari para partisipan, sehingga membutuhkan justifikasi berupa faktor lain yang dipercaya, berupa rekomendasi dari orang-orang atau temannya (Zhou, 2017). Pada penelitian ini, rekomendasi tersebut direpresentasikan dalam bentuk jumlah likes, sehingga atensi visual muncul apabila stimulus berupa harga yang mahal dibarengi dengan jumlah likes yang relatif banyak. Pembuktian terhadap dugaan ini memerlukan penelitian lebih lanjut.

Pengujian hipotesis terhadap hubungan antara durasi atensi visual dengan intensi pembelian (H5) dilakukan dengan menggunakan analisis regresi ordinal pada minitab. Hasil pengolahan data tersebut dapat dilihat pada Tabel 4. Nilai $p$ lebih besar dari 0,1 menunjukkan bahwa tidak ada hubungan antara tingkat atensi visual pada tampilan Instagram dengan intensi pembelian. Hasil penelitian ini menunjukkan bahwa tipe gambar dan jumlah likes mampu menarik atensi visual pemirsa. Informasi harga akan menarik atensi pemirsa jika disertai dengan jumlah likes. Namun demikian, atensi visual belum mampu mempengaruhi intensi pembelian produk. Hubungan antara atensi visual terhadap harga dengan intensi pembelian dilakukan pada penelitian oleh Huddleston (2015), yang menemukan bahwa informasi produk pada penanda (sign) tanpa informasi harga menghasilkan intensi membeli yang lebih tinggi daripada penanda yang mencantumkan informasi harga.

Peneliti kemudian melakukan pengujian lebih lanjut untuk mengetahui apakah ada faktor lain yang signifikan mempengaruhi intensi pembelian. Hasil pengolahan data menunjukkan bahwa informasi harga berpengaruh signifikan pada sikap terhadap produk, dan sikap terhadap produk berpengaruh signifikan terhadap intensi pembelian.

Di samping itu, faktor kepercayaan diduga memediasi hubungan antara media sosial dengan intensi membeli. Studi literatur yang dilakukan oleh Hakansson dan Witmer (2015) menunjukkan bahwa ada hubungan signifikan antara media sosial dengan rasa percaya. Sementara hubungan antara rasa percaya dengan intensi membeli dan perilaku berbelanja daring dikemukakan oleh Xu (2015) dan Hong-You dkk (2016). Menurut penelitian Irwanda (2014), pelanggan potensial lebih memilih untuk melakukan transaksi dengan toko daring yang dianggap dapat dipercaya walaupun mengenakan harga premium. 
Implikasi dari penelitian ini adalah, promosi produk melalui Instagram yang menampilkan gambar produk disertai dengan informasi harga dan jumlah likes relatif banyak akan menarik atensi visual pemirsa. Sementara intensi pembelian akan meningkat jika informasi harga yang ditampilkan pada post Instagram membangkitkan sikap positif terhadap produk.

\section{Kesimpulan}

Dari empat faktor yang diuji terhadap tingkat atensi di Instagram, hanya dua faktor yang mempunyai pengaruh langsung dan signifikan terhadap tingkat atensi terhadap post Instagram yakni tipe gambar dan jumlah likes. Di samping itu, terdapat interaksi yang signifikan antara faktor jumlah likes dengan informasi harga dalam mempengaruhi tingkat atensi visual pemirsa Instagram. Namun demikian, atensi visual tidak berpengaruh signifikan terhadap intensi pembelian.

\section{Daftar Pustaka}

Abdurrahman, M. S. (2017, Mei 20). Pertumbuhan eCommerce Indonesia Tertinggi di Dunia. Retrieved from Liputan 6: https://m.liputan6.com/tekno/read/2957050/pertu mbuhan-e-commerce-indonesia-tertinggi-didunia

Bakhshi, S., \& Gilbert, E. (2015). Red, Purple, and Pink: The Colors of Diffusion on Pinterest. PLoS One.

Bakhtiar, A., Jayanto, D. (2015). Analisis ElemenElemen Brand Equity Pada Produk Kartu Seluler Prabayar Simpati, IM3, dan XL di Kalangan Mahasiswa S1 Universitas Diponegoro, Jurnal Teknik Industri, X(3), 155-162.

Belch, G. E. (2004). Advertising and promotion: An Integrated Marketing Communication Perspective. New York: McGraw-Hill.

Bojko, A. (2006). Using eye tracking to compare web page designs: a case study. Journal of Usability Studies, 112-120.

Bojko, A. (2013). Eye Tracking The User Experience. New York: Rosenfeld.

Hakansson, P., and Wijmer, H. (2015). Social Media and Trust - A Systematic Literature Review. Journal of Business and Economics, 6 (3), 517524

Hong-You, H., John, J., John, J., \& Chung, Y. (2016). Temporal Effects on Information from Social Networks on Online Behavior. Internal Research, 213-235

Hootsuite. (2018). Extrapolation of Data From Facebook. Los Angeles: Hootsuite.

Huddleston, P., Behe, B.K., Minahan, S., Fernandez, R.T. (2015) "Seeking attention: an eye tracking study of in-store merchandise displays", International Journal of Retail \& Distribution Management, Vol. 43 (6), hal.561-574
Irwanda, A. (2014). Pengaruh harga dan kepercayaan terhadap intensi pembelian online studi kasus: zalora.com. Tesis. Depok: Universitas Indonesia.

Khan, S. (2012). Brand Awareness through Social Media Marketing and its Impact on Purchase Decisions of Customers: An empirical study. Global Journal of Finance and Management, 4.

King, C. (2015, October 7). What types of photos get the most like on Instagram. Diambil kembali dari https://www.socialmediatoday.com/marketing/ca rianneking/2015-10-07/what-types-photos-getmost-likes-instagram-infographic

Laroche, M., Kim, C., \& Zhou, L. (1996). Brand familiarity and confidence as determinants of purchase intention; An empirical test in a multiple brand context. Business Research Journal, 115-120.

Menon, R. V. (2016). Consumer attention to price in social commerce: Eye tracking patterns in retail clothing. Journal of Business Research, 50085013

Miles, J. (2015). Instagram Power. USA: McGraw-Hill Education Books.

Moreau. (2016, Mei 4). What Is Instagram, Anyway? Diambil kembali dari Lifewire: http://www.lifewire.com/what-is-instagram3486316

Ohman, W. (2017). Instagram Marketing: A Study about the effect of visual content on customer engagement in the airline study, Tesis, University of Reykjavik.

Pearson, M. (2008). Sistem Informasi Manajemen. Jakarta: Salemba.

Pechmann, C., Stewart, D.W. (1990). The Effects of Comparative Advertising on Attention, Memory, and Purchase Intentions. Journal of Consumer Research, 17(2), hal. 180-191

Pretorius, M., Calitz, A.P. (2011). The Contribution of Eye Tracking to Brand Awareness Studies, In Fifth International Business Conference. Turtle Bay, Mauritius.

Shojaee, S., \& Azman, A. b. (2013). An evaluation of factors affecting brand awareness in the context of social media in Malaysia. Asian Social Science, $72-78$.

Sjoberg, A. (2017). Influencing Brand Awareness Through Social Media. Finland: ARCADA

Small, D. A., \& Verrochi, N. (2009). The face of need: Facial emotion expression on advertisement. Journal of Marketing Research, 777-787.

Wagner, T. (2007). Shopping motivation revised: A means-end chain analytical perspective. International Journal of Retail \& Distribution Management, 569-582.

Xu, Y. (2015). Understanding Local Facebook Yard Sales Communities: The Relationship Between 
Trust, Facebook Use, and Sense of Community. Thesis Bowling Green State University

Zhou, L. (2017). How Visual Communication Strategies, Brand Familiarity, and Personal Relevance Influence Instagram Users' Response to Brand Content. Disertasi: University of Southern Mississippi. 